\title{
Cultured Meat: Islamic and Other Religious Perspectives
}

Mohammad Naqib Hamdana ${ }^{*}$, Mark Post ${ }^{\mathrm{b}, \mathrm{c}}$, Mohd Anuar Ramlid, Mohd Khairy Kamarudina, Mohd Farhan Md Ariffine, Nek Mohd Farid Zaman Hurif

Islamic Civilization Academy, Universiti Teknologi Malaysia, 81310 UTM Johor Bahru, Johor

- Department of Physiology, Maastricht University, Netherlands

‘Mosa Meat, Besloten Vennootschap Ltd., Watermolen 28, 6229 PM, Maastricht, The Netherlands

¿Academy of Islamic Studies, Universiti Malaya, 50603 Kuala Lumpur

eResearch Centre for Quran and Sunnah, Faculty of Islamic Studies, Universiti Kebangsaan Malaysia, 43600 Bangi, Selangor

fDindings Poultry Processing Sdn Bhd, Kampung Acheh Industrial Estate, 32000 Sitiawan, Perak.

*Corresponding author:mohammadnaqib@utm.my

\section{Article history}

Received: 2020-06-30 Received in revised form: 2021-05-21 Accepted: 2021-05-25 Published online: 2021-06-30

\begin{abstract}
Cultured meat is one of the most promising idea in food technology and it is expected to be in the market in the following years. One of the main obstacles is the acceptance of consumers that follow their religious teaching about food consumption, including meat. This article will discuss the religious perspectives on cultured meat, especially from the Islamic Law view. This study has implemented qualitative research and applied document analysis from the collected data of various sources. The result shows that there was high probability of cultured meat acceptance in the majority of the religions if the production complies with their religious meat dietary teaching. Further research must be done to investigate the acceptance of cultured meat among religious followers.
\end{abstract}

Keywords: cultured meat, religious perspectives, science and technology, religious ethics 


\subsection{INTRODUCTION}

The idea of producing meat by cell and tissue culture has been initiated in late 19th century Victorian science fiction literature (Young, 2019) and the concept has been reiterated by Winston Churchill in 1932 (Churchill, 1932). However, it took until 2003 for the first small cultured meat objects to be constructed, originally as an art project by Oron Catts (Zurr \& Catts, 2017). More than a decade later, Mark Post laboratory presented the world's first cultured hamburger from bovine muscle stem cells (Post, 2014). Simultaneously, other researchers ventured into culturing leather from skin cells or milk using recombinant technology. The field that uses biotechnology to recreate animal products instead of traditional agricultural methods was collectively referred to as 'cellular agriculture'. The widespread media coverage, together with the increasing public concern about the impact of environmental and animal welfare on livestock agriculture have triggered the rapid growth of privately funded startup companies that strive to bring cultured meat and other cellular agriculture products to the market.

Culturing meat is an important alternative to livestock meat production because it can theoretically follow the increasing global demand for meat with much reduced impact on the environment (Tuomisto, Ellis \& Haastrup, 2014; Mattick, Landis, Allenby \& Genovese, 2015). However, the technology is complex and not immediately suitable for large scale production at reasonable cost. This is illustrated by the long period between the proof concept provided in 2013 and the market introduction of the first products, which has yet to come. Apparently, this will happen sometimes during the next three years. The challenges are not limited to the technical process. It is clear that the consumers will have initial reservations against products that have been described as 'labgrown', although surveys on the subject are encouraging (Bryant \& Barnett, 2018). These surveys tend to cover general populations in various geographical locations and are typically not targeted to specific consumer groups yet. Finally, the safety of cultured products needs to be assured through government regulatory approval, in Europe for instance, which is dictated by the novel food regulation.

The technology is based on stem cells that have tremendous proclivity for proliferation, and this multiplication is essential to reduce the number of animals required as stem cell 'donors.' Stem cells maintain the capacity to differentiate into muscle cells or fat cells, together with the principal elements of meat. Through this technology, meat can be made from all species commonly employed in livestock agriculture, from bird, mammal and fish kingdoms. The stem cells can be retrieved from animal through a biopsy. Up to a few grams of tissue are taken per biopsy with little consequences for the donor. Multiple biopsies can be taken per animal. Alternatively, the donor animal is slaughtered and all of its stem cells are retrieved. The technology to scale up stem cell retrieval from the whole animals has not been developed yet.

Some researchers used tissue-specific stem cells, such as muscle satellite cells or adiposederived stem cells of fat tissues (Post \& Weele, 2013). Others used induced pluripotent stem cells (iPSCs), made from regular tissue cells, but reprogrammed back into stem cells through the insertion of four embryonic genes, known as the Yamanaka factors (Liu et al., 2008). iPSCs have the advantages where they have an even better proliferative capacity, perhaps at some time in the future, obviating the need for animal donors. In some cultures, however, genetic modification is required to make these cells an obstacle for public acceptance and regulatory approval. For oviparous animals such as birds and fish, it is possible to use various embryonic stages of fertilised eggs as cell source.

During proliferation and differentiation, the cells need to be nurtured and stimulated. Nourishment is provided by culture medium, fluid that contains glucose, amino acids, vitamins, minerals and other components essential for growing new cells. The fluid also contains stimulants that 
are delivered by adding fetal-calf serum, a blood product from unborn calves (Hodgson, 1995). Many effective 'serum-free' solutions are commercially available and they typically consist of a mixture of recombinant growth factors. The precise composition of the mixture is cell and species-specific (van der Valk et al., 2010), suggesting that for every application, proprietary formulations need to be established. In contrast, the nutrient component of the medium is more generic.

To reap all the potential benefits of culturing meat, all components need to be animal-free except for the stem cells. Currently, alternatives for those non-replicative components, are synthetically produced or plant-derived (Ben-Arye \& Levenberg, 2019). As stem cells can multiply, their continued use for meat production allows for a much-reduced number of animals with positive consequences for food security, environment and animal welfare. The cultured meat technology has been described as disruptive and for sure, once successful, it will lead to huge transformations in the agricultural industry and in society in general. However, these transformations take decades to replace the current production volume by cultured meat. Likewise, it takes time for the population to select products from cellular agriculture over familiar products from conventional agriculture.

Besides the discussion about new advancement and achievement in cultured meat research, the acceptance of the cultured meat among consumers must also be one of the concerns, especially for the consumers who practice certain religious diet. For example, Muslim consumers practice halal diet, Jews consumers practice kosher diet and so on. Therefore, this article will discuss on Islamic dietary law and its view towards cultured meat. Then, we will also examine other religious perspectives on cultured meat from their scholars' and experts' opinions.

\subsection{METHODOLOGY}

Qualitative approach was employed to describe and interpret a phenomenon (Auta, StricklandHodge, \& Maz, 2017) as in this study which explored religious perspectives on cultured meat. Document analysis as proposed by Bowen, (2009) was conducted by exploring hadis, tafsir, commentaries of al-Quran and Hadith, main references from four Islamic schools of thought (Syafie, Maliki, Hanafi and Hanbali) and scholars' article journal, websites and newspapers particularly Judaism, Buddhism, Christianity, Sikhism and Hinduism opinions. The data was analysed using content analysis technique as initiated by (Elo et al., 2014) which involved three main phases; Preparation Phase, Organisation Phase and Reporting Phase.

\subsection{RESULT}

\subsection{Islam and Cultured Meat}

Several Muslim scholars suggested the prohibition of cultured meat for Muslims due to its production process that violates the natural law, which can be understood as 'playing God' and also known as taghyir khalqillah. They mentioned that this kind of new meat production is evading the nature and categorised under 'playing God'. They also described cultured meat as an experiment with nature that has no benefit (Gross, 2014; Hossain, 2019; Sugden \& Malhotra, 2013) by referring to the Quranic text, surah al-Nisa', Chapter 4, verse 119:

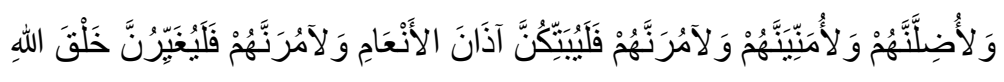

Translation: (Satan said): I will mislead them and incite vain desires in them; I will command them to slit the ears of cattle; I will command them to tamper with God's creation (playing God) (Quran, al-Nisa' 4: 119). 
In order to gain a better understanding of the concept of 'playing God', we have studied and analysed this concept by referring to the primary Islamic source that interprets this verse. Twelve classical Muslim scholars (known as mufassirin) was chosen. Contemporary Muslim scholars often used this concept to prohibit some of the human activities that alter God's creation, such as human cloning and cosmetic surgery for the purpose of enhancement with no medical prescription (Hamdan \& Ramli, 2015). The twelve classical Muslim scholars that have been referred to are; al-Tabari (d.922), al-Jassas (d.980), al-Zamakhshari (d.1143), Ibn al-'Arabi (d.1148), Ibn 'Atiyyah (d.1151), al-Razi (d.1209), alQurtubi (d.1272), Abu Hayyan al-Andalusi (d.1344), Ibn Kathir (d.1372), al-Shawkani (d.1834), Muhammad 'Abduh (d.1905) and Muhammad Rashid Rida (d.1934) [d.= died]. They are selected from various backgrounds; school of thoughts and periods.

The results have shown that there are two kinds of 'alteration of God's creation'. First, metaphysical alteration such as 'change the God's rule' and 'serve the creation, not the God'. This kind of alteration is prohibited because it involves the pillars of Islam. Second is physical alteration that involves humans and animals, which are divided into three aspects; (i) temporary and permanent alteration, (ii) the purpose of alteration and (iii) the results of alteration. The Islamic ruling law of any acts that alter God's creation depend on the second and third aspects; the purpose and the results (Abduh, 1993; Abu Hayyan, 1993; Al-Jassas, 1984; Al-Qurtubi, 2006; Al-Razi, 2000; Al-Shawkani, 1992; Al-Tabari, 2000; Al-Zamakhshari, 2009; Atiyyah, 2001; Ibn al-'Arabi, 1976; Ibn Kathir, 1999; Reda, 1990).

This is why several contemporary Muslim scholars have banned organ transplantation in their early fatwa because of the risk of death after organ transplantation procedure. However, they changed it after they concluded that the process and the purpose of organ transplantation have produced benefits to mankind. Fatwa is the decision or the legal outcome of an independent interpretation, also known as ijtihad. Although cultured meat is included in the concept of alteration of God's creation or 'playing God', we believe that cultured meat as a new meat production concept is allowed due to its purpose to fulfill human meat consumption and the results will benefit humanity in general.

Muslim community apply balalan tayyiban diet, derived from Islamic teaching. There are four main aspects for cultured meat production in order to fulfill the halalan tayyiban diet, ie.; (i) source of meat and stem cell, either from embryonic stem cells and adult stem cells, (ii) culture medium, (iii) the slaughtering process and (iv) halal certification.

Meat and stem cells must be extracted from halal animals such as cow, camel, chicken, and others, and they are slaughtered according to the Islamic teaching. The livestock that are not properly slaughtered according to the Islamic teaching will be categorised as carcass and forbidden to be eaten by Muslims. If the stem cells was taken from carcass or when the animal is still alive, then the produced cultured meat is unclean and forbidden to be eaten because the hadith clearly forbids it. This ruling applies to all types of livestock except pig because it is definitely forbidden by Allah as mentioned in the Quran, Surah al-Baqarah, Chapter 2, verse 173.

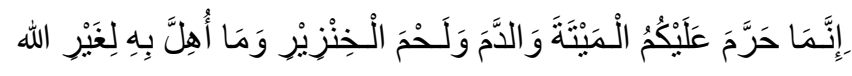

Translation: He has prohibited you (from consuming) carcass, blood and the flesh of swine and (the livestock that slaughtered) upon a name of someone other than Allah (Quran, alBaqarah 2: 173).

Nonetheless, marine life are not included in this ban as there are other hadiths stated that marine life is permitted and halal despite their carcass condition. Therefore, if the marine carcass is lawful to be consumed, then any body parts being cut off are also lawful and halal. Hence, any cultured meat originating from marine life is considered permissible even if the stem cells are taken when the marine 
life is still alive. Abu Hurairah radiyallahu 'anhu narrated badith from Prophet Muhammad peace be upon bim:

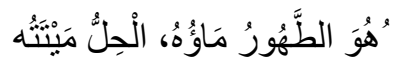

Translation: Its water is purifying and its dead (animals) are lawful (to eat) (reported by Ibn Khuzaimah, al-Tirmidhi and Malik. Ibn Khuzaimah and al-Tirmidhi graded this badith as sabib) (Al-Bassam, 2003; Al-Sa'ati, 2006; Al-Tirmidhi, 2000; Anas, 1997).

Normally, culture medium that is used in the culturing process is serum, extracted from animal blood via a separation technique called centrifugation to separate blood cells, platelets and clotting factors. Because of the source of serum which is originated from blood, the serum is categorised as unclean according to the previous Quranic verse, and may lead to unclean cultured meat. However, if the culture medium is made of mushroom extract, plant-based medium or a mixture of chemical artificial medium, then the meat is halal since plant-based medium or chemical medium are not considered as unclean ingredient. It should be ensured that the artificial medium used is non-toxic and non-harmful (Hamdan, Post, Ramli, \& Mustafa, 2018).

Islam has set certain conditions in slaughtering process, which covers the conditions of the animal, the slaughterer and the tool used for slaughter. The main conditions for animal to be slaughtered are; (i) The animal must be alive during the slaughtering process; (ii) the animal must only die completely due to the act of slaughtering; and (iii) the animal is not hunted by the people who are in ibram, a sacred state in which a Muslim must follow in order to perform the major pilgrimage (Hajj) or the minor pilgrimage ( Umrah). The conditions for the slaughterer are; (i) sane; (ii) Muslim or people of the books (Ahl al-Kitab; such as Christian or Jews); (iii) not in a state of Ihram; and (iv) invoking the name of Allah Glory upon Him or recite bismillah. As for the slaughtering tool; (i) The knife must be able to cut smoothly and extremely sharp to quickly cut the skin and severe off the blood vessels to enable the blood flow immediately; and (ii) it is not made of teeth or claws (Kuwait, 1986).

The previous discussion analysed on how to make cultured meat acceptable in Islam. However, another important aspect is the process of producing cultured meat must receive the halal certification from halal organisations in the production country. For example, if a meat company in Netherlands wants to produce cultured meat and then export the meat to a Muslim country, they are encouraged to apply for halal certificates from the halal organisations and authorities in Netherlands; (i) Control Office of Halal Slaughtering and Halal Quality Control, (ii) Total Quality Halal Correct Certification and (iii) Halal Feed and Food Inspection Authority. This is because there are some Muslim countries that require halal certification from the authorities before the meat can be exported to their countries, such as Malaysia (JAKIM, 2019). In fact, through this halal certificate, the Muslim community will be more confident to consume the cultured meat that has received recognition from the halal official bodies. Studies have also shown that halal certification enhances the Muslim community's interest in buying a product (Aziz \& Chok, 2013).

\subsection{Other Religious Perspectives on Cultured Meat}

Similar to Muslim communities that apply halal diet in their daily food consumption, other religions also have their own diet obtained from their religious teachings. For example, Jews have their own dietary law called kosher as a parameter for Jewish to consume food. Kosher diet ensures that the ingredients and the procedures are parallel with kosher law (Blech, 2009). Unlike the halal diet for Muslims that is purposely practised for health and religious ritual (ibadab), the main purpose of kosher dietary law is not for health but holiness (Siegel \& Siegel, 1966). In Kosher diet, there are several animals prohibited to Jews such as pig, camel, wild bird, shark and catfish (Regenstein, Chaudry \& Page $\mid 15$ 
Regenstein, 2003). They also practice slaughtering before it is lawful to be eaten with certain rules to ensure that the meat is religiously clean (Tieman \& Hassan, 2015). There is a discussion among Jewish Rabbi and as a result, they accepted cultured meat as kosher meat because it has lost the original identity as a meat. Some Rabbi said that cultured meat from pig should not be prohibited for consumption by Jews. Other Rabbi viewed that cultured meat must be derived from animals that are slaughtered using the kosher procedures. They viewed that cultured meat is still meat (Banis, 2018; Chriki \& Hocquette, 2020; JTA \& TOI, 2018; Krautwirth, 2018) The definition of 'cultured meat' has led to these two opinions. If 'cultured meat' is defined as meat, it will go through the same concept of kosher meat. But if 'cultured meat' is defined as cloned meat and it is not normal meat, it can be eaten even it is the pork cultured meat which is prohibited to be eaten in its original meat. While Kenigsberg and Zivotofsky (2020) emphasizes the source of stem cell and culturing methods used to produce cultured meat. This is not much different from the conditions set by Muslim scholars to produce halal cultured meat (Hamdan, 2018).

Hindus apply three types of diet; vegetarian, lacto-vegetarian and non-vegetarian. Vegetarian and lacto-vegetarian diet is the practice of abimsa concept in Hinduism, which means "no to injure" or "compassion". As a consequence, the majority of Hindus apply these two types of diet as a respectful way to the nature and other life form. As a result, they only eat non-animal food, excluding meat and egg for lacto-vegetarian. Non-vegetarians eat like other people including meat and dairy products. According to the survey in 2016 that was carried out in India with the biggest nation of Hindus, $70 \%$ of Indians were non-vegetarian. However, they still practised vegetarian diet on some occasions. Eating beef is prohibited because cow is a sacred animal to Hindus (Anonymous, 2020; Bose, 2016; Cohen, 2018; McCaffree, 2002). When cultured meat was introduced to the world, there were some Hindu scholars who did not agree with the achievement and they described 'the use of animal cells to make meat constitutes an example of human arrogance' (Gross, 2014). Some of them would not recognise it as vegetarian because it still uses animal cells as a source to produce cultured meat (Sugden \& Malhotra, 2013; Bryant, 2020). But some scholars claimed that it may be accepted according to abimsa practice (Jagadeesan \& Salem, 2020). Sikhism, Buddhism and Jainism might also have the same belief on cultured meat because they also apply vegetarianism in their diet, and in some conditions, vegetarianism in Jainism is stricter than Hinduism (Editors, 2018; Foodie, 2011; Heneghan, 2013; Project, 2016; Resse, 2018). However, there are some Sikhs and Buddhists who eat meat. For example, Sikhs who eat Jhatka meat - the meat from animals that are killed instantaneously - has the probability to eat this kind of meat if the source of cells comes from this kind of meat. The Buddhists who practise Shojin Ryori diet may not eat cultured meat (Ambros, 2019) but there are some Buddhism schools that allow their followers to eat certain kind of meat and it is possible for them to eat cultured meat (Brahmavamso, 1990; "Do Buddhists Eat Meat?," 2017; Bryant, 2020). In contrast, Christianity allows their followers to eat any kind of meat because all meat is clean according to their religious practice. As a result, cultured meat might not be a problem for them to be consumed once it is ready in the market (Brattston, n.d.; Stefon \& Cohen, 2018; Truth, n.d.; Jagadeesan \& Salem, 2020).

\subsection{CONCLUSION}

In conclusion, cultured meat is one of the new meat products that has been created with the development and advancement of science and technology. One of the main objectives of cultured meat creation is to fulfil the needs and demands of meat-based products in the market. It is also expected to address the problem of insufficiency of meat, but its effectiveness is yet to be proven as it has not yet entered the mass market.

The cultured meat must meet the standard and criteria set by each religion before the consumers who practice certain religious dietary laws can eat it. This is very important, especially for those who Page $\mid 16$ 
are practicing their religious dietary tightly. In addition, the study on the acceptance of consumers who are practicing certain diets, either from their religious teachings or their beliefs, is also essential. It can be beneficial for cultured meat mass production.

\section{References}

Abduh, M. (1993). Fi Tafsir al-Qur'an. In M. 'Imarah (Ed.), al-A'mal al-Kamilab li al-Imam al-Sheikh Muhammad Abduh (1st ed.). Cairo: Dar al-Shuruq.

Abu Hayyan, M. bin Y. (1993). al-Babr al-Mubit. Beirut: Dar al-Kutub al-'Tlmiyyah.

Al-Bassam, A. 'Abdul R. (2003). Tawdih al-Abkam min Bulugh al-Maram. Mekkah: Maktabah al-Ansari.

Al-Jassas, A. 'Ali al-R. (1984). Abkam al-Qur'an. (M. al-S. Qamhawi, Ed.). Beirut: Dar Ihya' al-Turath al-'Arabi.

Al-Qurtubi, M. A. A. B. (2006). Al-Jami' li Abkam al-Qur'an. (A. bin 'Abd al-M. Al-Turki, Ed.). Beirut: Muassasah al-Risalah.

Al-Razi, F. al-D. M. ibn 'Umar. (2000). Mafatih al-Ghayb (1st ed., Vol. 27). Beirut: Dar al-Kutub al-'Ilmiyyah.

Al-Sa'ati, A. 'Abd ul R. al-B. (2006). Subul al-Salam Sharb Bulugh al-Maram. (M. N. al-D. Al-Albani, Ed.). Riyad: Maktabah al-Ma'arif.

Al-Shawkani, M. A. (1992). Fath al-Qadir al-Jami' bayn Fannai al-Riwayah wa al-Dirayah min 'Ilm al-Tafsir. (S. M. AlLahham, Ed.) (1st ed.). Beirut: Dar al-Fikr.

Al-Tabari, M. J. Y. (2000). Jami' al-Bayan 'an Ta'wil Ayi al-Qur'an. (M. M. Shakir \& A. M. Shakir, Eds.). Beirut: Muassasah al-Risalah.

Al-Tirmidhi, A. 'Isa M. bin 'Isa S. (2000). Sunan al-Tirmidhi. (S. bin 'Abd al-'Aziz Ali al-Sheikh, Ed.) (2nd ed.). Riyad: Dar al-Salam.

Al-Zamakhshari, M. 'Umar. (2009). Tafsir al-Kashshaf 'an Haqa'iq al-Tanzil wa 'Uyun al-Aqawil fi Wujuh al-Ta'wil. (K. Ma'mun, Ed.) (3th ed.). Beirut: Dar al-Ma'rifah.

Ambros. (2019). Partaking of Life: Buddhism, Meat-Eating, and Sacrificial Discourses of Gratitude in Contemporary Japan. Religions, 10(4), 279. https://doi.org/10.3390/rel10040279

Anas, M. (1997). al-Muwatta'. (Bashshar 'Awwad Ma'ruf, Ed.). Beirut: Dar al-Gharb al-Islami.

Anonymous. (2020, March). Diet in Hinduism. Wikipedia.

Atiyyah, A. al-H. G. (2001). al-Muharrar al-Wajiz fi Tafsir al-Kitab al-Azi: (A. al-S. A. Al-Shafi, Ed.) (1st ed.). Beirut: Dar al-Kutub al-'Tlmiyyah.

Auta, A., Strickland-Hodge, B., \& Maz, J. (2017). There is still a case for a generic qualitative approach in some pharmacy practice research. Research in Social and Administrative Pharmacy, 13(1), 266-268.

Aziz, Y. A., \& Chok, N. V. (2013). The Role of Halal Awareness, Halal Certification, and Marketing Components in Determining Halal Purchase Intention Among Non-Muslims in Malaysia: A Structural Equation Modeling Approach. Journal of International Food \& Agribusiness Marketing, 25(1), 1-23. https://doi.org/10.1080/08974438.2013.723997

Banis, D. (2018, October). How Israel Became The Most Promising Land For Clean Meat. Forbes.

Ben-Arye, T., \& Levenberg, S. (2019). Tissue Engineering for Clean Meat Production. Frontiers in Sustainable Food Systems, 3. https://doi.org/10.3389/fsufs.2019.00046

Blech, Z. Y. (2009). Kosher Food Production. Oxford, UK: Wiley-Blackwell. https://doi.org/10.1002/9780813804750

Bose, A. (2016, June). Vegetarian India A Myth? Survey Shows Over 70\% Indians Eat Non-Veg, Telangana Tops List. Huffingtonpost.

Bowen, G. A. (2009). Document analysis as a qualitative research method. Qualitative Research Journal, 9(2), 27Page $\mid 17$ 
40. https://doi.org/10.3316/QRJ0902027

Brahmavamso, A. (1990, June). What the Buddha Said About Eating Mea. Urbandharma.Org.

Brattston, D. W. T. (n.d.). It is not a sin for Christians to eat test tube meat and genetically modified foods!

Braun, V., \& Clarke, V. (2006). Using thematic analysis in psychology. Qualitative Research in Psychology, 3(2), 77 101. https://doi.org/10.1191/1478088706qp063oa

Bryant, C., \& Barnett, J. (2018). Consumer acceptance of cultured meat: A systematic review. Meat Science, 143, 8-17. https://doi.org/10.1016/j.meatsci.2018.04.008

Bryant C. J. (2020). Culture, meat, and cultured meat. Journal of Animal Science, 98(8), 1-7. https://doi.org/10.1093/jas/skaa172

Chriki, S., \& Hocquette, J. F. (2020). The Myth of Cultured Meat: A Review. Frontiers in Nutrition, 7. https://doi.org/10.3389/ fnut.2020.00007

Churchill, W. (1932). Thoughts and Adventures. London: Thornton Butterworth.

Cohen, M. S. Y. A. (2018). Dietary Law; Hinduism. In Britannica. Encyclopædia Britannica, inc.

Do Buddhists Eat Meat? (2017). Buddism Zone.

Editors, T. (2018, October). Is Lab Grown Meat Ethical? The Daily Englightment.

Elo, S., Kääriäinen, M., Kanste, O., Polkki, T., Utriainen, K., \& Kyngas, H. (2014). Qualitative Content Analysis: A Focus on Trustworthiness. SAGE Open, 4(1), 1-10.

Foodie, J. (2011). Jain Food Restrictions. JainFoodie.Com.

Gross, R. (2014, September). How will religious authorities deal with lab-grown meat? Genetic Literacy Project.

Hamdan, M. N., Post, M. J., Ramli, M. A., \& Mustafa, A. R. (2018). Cultured Meat in Islamic Perspective. Journal of Religion and Health, 57(6), 2193-2206. https://doi.org/10.1007/s10943-017-0403-3

Hanna L. Tuomisto, Marianne J. Ellis, \& Palle Haastrup. (2014). Environmental impacts of cultured meat: alternative production scenarios. In Rita Schenck \& Douglas Huizenga (Eds.), Proceedings of the 9th International Conference on Life Cycle Assessment in the Agri-Food Sector (LCA Food 2014), 1360-1366. San Francisco: ACLCA, Vashon, WA.

Heneghan, T. (2013, August). Religions asking if test-tube burgers allow them to keep the faith. Reuters.

Hodgson, J. (1995). To Treat or Not to Treat: That Is the Question for Serum. Nature Biotechnology, 13(4), 334 337. https://doi.org/10.1038/nbt0495-333

Hossain, M. S. (2019). Consumption of Stem Cell Meat: An Islamic Perspective. IIUM Law Journal LJ, 27(1), 233-257. https://doi.org/10.31436/iiumlj.v27i1.384

Ibn al-'Arabi, M. 'Abdullah. (1976). Abkam al-Qur'an. (A. M. Al-Bijawi, Ed.) (2nd ed.). Kaherah: Matba'ah 'Isa al-Babi al-Halabi.

Ibn Kathir, I. U. (1999). Tafsir al-Qur'an al-'Azim. (S. bin M. Al-Salamah, Ed.). Riyad: Dar Tibah.

Ionat Zurr, \& Oron Catts. (2017). Tissue Engineering for Art, Design, and Other Cultural Artifacts. In J. P. Vacanti (Ed.), Tissue Engineering and Regenerative Medicine (1st ed., pp. 147-157). United States: Cold Spring Harbor Laboratory Press.

JAKIM, J. K. I. M. (2019). The Recognised Foreign Halal Certification Bodies and Authorities. Putrajaya.

Jagadeesan, P., Salem, S. (2020). Religious and Regulatory concerns of animal free meat and milk. Science Open Preprints, 10.14293/S2199-1006.1.SOR-.PP7B21S.v1

Joanna Sugden, \& Aditi Malhotra. (2013, August). In India, Lab-Grown Beef Still Taboo. The Wall Street Journal.

JTA, \& TOI. (2018, March). Rabbi: Lab-grown pork could be kosher for Jews to eat - with milk. The Time of Israel. 
Kenigsberg, J. A., Zivotofsky, A. Z. (2020). A Jewish Religious Perspective on Cellular Agriculture. Frontier Sustainable Food System, 3(128), 1-6https://doi.org/10.3389/fsufs.2019.00128

Krautwirth, R. (2018, May). Will Lab-Grown Meat Find It's Way to Your Table? The Yeshiva University Observer.

Kuwait, W. M. (1986). al-Dhaba'ih. In al-Mawsu'ah al-Fiqbiyyah al-Kuwaitiyyah , 171-204. Dhat al-Salasil.

Liu, X., Huang, J., Chen, T., Wang, Y., Xin, S., Li, J., .. Kang, J. (2008). Yamanaka factors critically regulate the developmental signaling network in mouse embryonic stem cells. Cell Research, 18(12), 1177-1189. https://doi.org/10.1038/cr.2008.309

Mark J. Post, \& van der Weele. (2013). Principles of Tissue Engineering for Food. In Robert Lanza, Robert Langer, \& Joseph Vacanti (Eds.), Principles of Tissue Engineering , 4, 1647-165. Elsevier.

Matt Stefon, \& Yehudi A. Cohen. (2018). Dietary Law; Christianity. In Britannica. Encyclopædia Britannica, inc.

Mattick, C. S., Landis, A. E., Allenby, B. R., \& Genovese, N. J. (2015). Anticipatory Life Cycle Analysis of In Vitro Biomass Cultivation for Cultured Meat Production in the United States. Environmental Science \& Technology, 49(19), 11941-11949. https://doi.org/10.1021/acs.est.5b01614

McCaffree, J. (2002). Dietary Restrictions of Other Religions. Journal of the American Dietetic Association, 102(7), 912. https://doi.org/10.1016/S0002-8223(02)90212-9

Naqib Hamdan, M., \& Anuar Ramli, M. (2015). Konsep Mengubah Ciptaan Allah SWT: Analisis Hukum Pengkulturan Daging. Jurnal INFAD.

Post, M. J. (2014). An alternative animal protein source: cultured beef. Annals of the New York Academy of Sciences, 1328(1), 29-33. https://doi.org/10.1111/nyas.12569

Project, S. (2016). Cultured meat fit for Buddhist cuisine? Medium.Com. https://medium.com/shojin-meat/invitro-meat-fit-for-buddhist-cuisine-d6321 ca46b68

Reda, M. R. A. (1990). Tafsir al-Mannar. Kaherah: al-Hai'ah al-Misriyyah al-'Ammah.

Regenstein, J. M., Chaudry, M. M., \& Regenstein, C. E. (2003). The Kosher and Halal Food Laws. Comprehensive Reviens in Food Science and Food Safety, 2(3), 111-127. https://doi.org/10.1111/j.1541-4337.2003.tb00018.x

Resse, J. (2018). The Expanding Moral Circle. In The End of Animal Farming, 1, 14. Massachusetts: Beacon Press.

Siegel, S., \& Syemour Siegel. (1966). The Jenish dietary laws (2nd ed.). New York: The Burning Bush Press.

Tieman, M., \& Hassan, F. H. (2015). Convergence of food systems: Kosher, Christian and Halal. British Food Journal, 117(9), 2313-2327. https://doi.org/10.1108/BFJ-02-2015-0058

Truth, T. (n.d.). Does the Bible restrict what foods Christians should eat?

van der Valk, J., Brunner, D., De Smet, K., Fex Svenningsen, Å., Honegger, P., Knudsen, L. E., Gstraunthaler, G. (2010). Optimization of chemically defined cell culture media - Replacing fetal bovine serum in mammalian in vitro methods. Toxicology in Vitro, 24(4), 1053-1063. https://doi.org/10.1016/j.tiv.2010.03.016

Young, P. (2019). The Victorians caused the meat eating crisis the world faces today - but they might help us solve it. 